\title{
Effectiveness of SMS based Extension Advisories on Farmers Adoption Behaviour
}

\author{
M. Murugan ${ }^{1}$ and C. Karthikeyan ${ }^{2}$ \\ ${ }^{1}$ Department of Agricultural Extension and Rural Sociology, \\ 2Directorate of Extension Education, \\ Tamil Nadu Agricultural University, Coimbatore - 641003.
}

\begin{abstract}
The study deals with analysis of impact of SMS based advisories on farmers adoption behaviour disseminated by institutions such as DEMIC (Domestic and Export Market Intelligence Cell), ACRC (Agro Climate Research Centre) and KVK (Krishi Vigyan Kendra) which were exclusively involved in the delivery of Market, Weather and Technology advisory respectively throughout Tamil Nadu. Totally $\mathbf{3 0}$ farmers from each of these institutions were identified through simple random sampling method which sum up to a total of 90 respondents. Data were analyzed through descriptive statistics - mean, standard deviation, frequencies, independent sample t-test and chi-square test. Results showed that the adoption of SMS based advisories was low among registered farmers of KVK as compared to that of ACRC and DEMIC. Majority (87.80\%) of the respondents had medium level of perception towards SMS based advisories. Most of the farmers reported that lack of access to an effective extension service (or) credible information source as the constraint to access the required information. Extension activities need to be strengthened through a combination of personal \& ICT based extension approach to meet out such gaps in future.
\end{abstract}

Key words: SMS based advisories, Farmers, Adoption behaviour, Perception, Constraints.

Farming is the main occupation among rural communities of India. Nearly 50 per cent of the population depends only on agriculture for their livelihood. Indian agriculture is dominated by marginal and small farmers (Census, 2011) is highly challenged by lack of appropriate information at right time to maximize the productivity. In this regard, farmers demand information pertaining to weather, plant protection, market advisories, government schemes, subsidies etc. If these information were provided to the farmers at right time definitely it will enhance their growth and development in Agriculture (Mittal and Mamta, 2012).

The emerging concept of ICT \& its application in extension can help the farming community to get accurate and timely information (Sidramappa et al., 2013). In the recent years, there is huge increase in mobile phone subscription among farmers. It is noticed that mobile phone industry is one of the emerging and fastest growing industry in India. The introduction of mobile phone has changed a lot in the field of information technology. Among different modern ICT tools, mobile phone has been considered as a widely accepted mode for transfer of agricultural technology not only in India but also in south Asian and African countries (Mittal and Mamta, 2012). With a mobile phone one can communicate the agricultural information through short message service (SMS) anywhere in the country. Mobile based SMS advisories in turn will help rural development

*Corresponding author email: murugantally9@gmail.com. and economic growth (Jayanthi and Asokhan, 2016). The information service, called Reuters Market Light or RML, sends SMS to farmers with information on prices, weather forecasts, crop advice, and general news items. The price information is expected to improve farmer's ability to negotiate with buyers and to enable them to arbitrage better across space (e.g., different sales outlet). Weather information is expected to help farmers reduce crop losses due to extreme weather events such as storms. Crop advisory information is expected to induce farmers to adopt new crop varieties and improve their cultivation practices (Fafchamps and Minten, 2012). Due to limited human resources in agricultural extension, farmer's information needs could not be satisfied at right time. Though there are several ICT extension approaches, the penetration of its services among farming community is minimal. The mobile short message service (SMS) emerged as a boon to transfer or disseminate agricultural information to the farmers on various aspects (Saravanan, 2010). The DEMIC, ACRC of TNAU and KVKs in Tamil Nadu state are sending SMS based Market, Weather and Technology advisories in Tamil version to the registered farmer's maximum 250 characters length of SMS were prepared in Tamil and sent periodically to the registered farmers by the above mentioned organisations. However the effectiveness of such SMS to farmers is not known. Hence, this paper focused on understanding this researchable issue framed with the following objectives: 
a. To analyze the profile characteristics of farmers receiving SMS based advisories in agriculture from various sources,

b. To find out the utilization behaviour of farmers towards Market, Weather and Technological advisories in agriculture,

c. To study the farmers decision making behavior on the adoption of SMS based advisories

d. To identify the constraints faced by the farmers in accessing the SMS based advisories.

\section{Material and Methods}

For this study the institutions such as DEMIC (Domestic and Export Market Intelligence cell of TNAU), ACRC (Agro Climate Research Centre, TNAU) and KVK (Krishi Vigyan Kendra, MYRADA) which were exclusively involved in the delivery of market, weather and technology advisories respectively throughout Tamil Nadu were selected. To study the effectiveness of mobile SMS based market, weather and technology advisories, the registered farmers of DEMIC, ACRC \& KVK were interviewed through a semi - structured interview schedule over telephone regarding the usefulness of SMS service and their technology adoption behaviour. Telephone based interview was resorted for data collection considering the budget available for the study. DEMIC and ACRC had the list of district wise registered farmers to receive SMS periodically. Accordingly, Erode district recorded maximum number of farmers to receive SMS from DEMIC and hence erode was selected. In the case of ACRC, Coimbatore district recorded maximum number of registered farmers to receive SMS on weather advisories. Accordingly Coimbatore district was selected to draw sample for collecting data for the study. The KVK, MYRADA located in Erode was purposively selected as it is one of the KVKs in Tamil Nadu state which send SMS based advisories regularly and continuously to farmers since long time. A list of farmers in the selected district who were registered for receiving SMS was obtained from the concerned office. Totally 30 farmers from each of the organization viz., DEMIC, ACRC and KVK were selected through simple random sampling method which sum up to a total of 90 respondents. The most effective independent variables were selected for the study based on reviews. Adoption and perception behavior of farmers were selected as dependent variables. Adoption is operationalised as the decision taken by a registered farmer to make use of the SMS based Market/ Weather/ Technology advisories sent by the study organizations (DEMIC, ACRC and KVK) as applicable to his farm. It is measured based on the perception of the registered farmer which was calculated based on the number of SMS advisories adopted considering the total number of relevant SMS received by the farmers. Statistical tools like descriptive statistics - mean, frequencies, and percentage, independent sample t-test and chi- square test were used. Farmers seeking perception towards SMS based agro advisories were prepared. The respondents were asked to state on a three point continuum viz., agree, undecided and disagree with the score of 3, 2 and 1 respectively. Based on the scores, the perception index was obtained by using the formula given as follows:

$$
\text { Perception Index }=\frac{\begin{array}{c}
\text { (Individual respondent' } \\
\text { score) }
\end{array}}{\text { (Total score ) }} \times 100
$$

The overall perception level of farmers towards mobile based agro advisories was obtained based on the identified class interval.

\section{Results and Discussion \\ Market advisories}

Table 1 , shows that half of the respondents $(50.00$ $\%$ ) were found to be old aged followed by middle aged $(40.00 \%)$ and remaining 10.00 per cent were young. About 36.67 per cent of the respondents were found to have undergone collegiate education followed by 30.00 per cent of the respondents had secondary education followed by $13.33,10,6.67$ and 3.33 per cent of the respondents were in primary, illiterate, middle and functionally literate level of education respectively. More than half $(60.00 \%)$ of the respondents had medium level of farming experience and 43.34 per cent of the respondents were medium farmers.

From Table 2, it is found that little more than half $(53.33 \%)$ of the respondents adopted the SMS based market advisories. Only 43.75 per cent of the respondents revealed that they will go for direct adoption. One-third of them said that they will go for adoption only after discussion about SMS with fellow farmers and one-fourth $(25.00 \%)$ of the respondents reported that they will go for adoption of SMS advisories only after discussion with agro input dealers.

\section{Weather advisories}

Result in the Table 1, shows that 70.00 per cent of the respondents were found to be old aged followed by middle aged $(16.67 \%)$ and remaining 13.33 per cent were young. More than one-third $(36.67 \%)$ of the respondents had collegiate education followed by $23.33,20,13.33$ and 6.67 per cent of the respondents were in primary, secondary, middle and illiterate level of education respectively. Majority $(70.00 \%)$ of the respondents had medium level of farming experience and 56.67 per cent of the respondents were medium farmers. Based on the result from the table, it can be revealed that more than half of the respondents $(56.67 \%)$ had adopted the SMS based weather advisories.

From Table 2, it is found that only 23.50 per cent of the respondents reported that they will go for direct adoption. About 35.30 per cent of the respondents said that they will go for adoption of SMS advisories 
Table 1. Distribution of respondents according to their profile

\begin{tabular}{|c|c|c|c|c|c|c|}
\hline \multirow[t]{2}{*}{ Variable } & \multicolumn{2}{|c|}{$\begin{array}{l}\text { Market advisory } \\
\text { (DEMIC) } n=30\end{array}$} & \multicolumn{2}{|c|}{$\begin{array}{l}\text { Weather advisory(ACRC) } \\
n \mathrm{n}=30\end{array}$} & \multicolumn{2}{|c|}{$\begin{array}{l}\text { Technology advisory } \\
(\text { KVK) } n=30\end{array}$} \\
\hline & Frequency & $\%$ & Frequency & $\%$ & Frequency & $\%$ \\
\hline \multicolumn{7}{|l|}{ Age } \\
\hline Young & 3 & 10.00 & 4 & 13.33 & 2 & 6.67 \\
\hline Middle & 12 & 40.00 & 5 & 16.67 & 6 & 20.00 \\
\hline Old & 15 & 50.00 & 21 & 70.00 & 22 & 73.33 \\
\hline Total & 30 & 100 & 30 & 100 & 30 & 100 \\
\hline \multicolumn{7}{|l|}{$F=4.550^{*}$} \\
\hline \multicolumn{7}{|l|}{ Educational status } \\
\hline Illiterate & 3 & 10.00 & 2 & 6.67 & 1 & 3.33 \\
\hline Functionally literate & 1 & 3.33 & 0 & 0 & 0 & 0 \\
\hline Primary education & 4 & 13.33 & 7 & 23.33 & 0 & 0 \\
\hline Middle education & 2 & 6.67 & 4 & 13.33 & 12 & 40.00 \\
\hline Secondary education & 9 & 30.00 & 6 & 20.00 & 8 & 26.67 \\
\hline Collegiate education & 11 & 36.67 & 11 & 36.67 & 9 & 30.00 \\
\hline Total & 30 & 100 & 30 & 100 & 30 & 100 \\
\hline \multicolumn{7}{|l|}{$F=4.216^{*}$} \\
\hline \multicolumn{7}{|l|}{ Farm size } \\
\hline Marginal farmer & 1 & 3.33 & 2 & 6.67 & 2 & 6.67 \\
\hline Small farmer & 6 & 20 & 5 & 16.67 & 4 & 13.33 \\
\hline Medium farmer & 13 & 43.34 & 17 & 56.67 & 9 & 30.00 \\
\hline Big farmer & 10 & 33.33 & 6 & 20 & 15 & 50.00 \\
\hline Total & 30 & 100 & 30 & 100 & 30 & 100 \\
\hline \multicolumn{7}{|l|}{$F=2.181 \mathrm{NS}$} \\
\hline \multicolumn{7}{|l|}{ Farming experience } \\
\hline Low & 6 & 20.00 & 6 & 20.00 & 3 & 10.00 \\
\hline Medium & 18 & 60.00 & 21 & 70.00 & 19 & 63.30 \\
\hline High & 6 & 20.00 & 3 & 10.00 & 8 & 26.70 \\
\hline Total & 30 & 100 & 30 & 100 & 30 & 100 \\
\hline \multicolumn{7}{|l|}{$F=4.557^{*}$} \\
\hline \multicolumn{7}{|l|}{ Adoption } \\
\hline Adopted & 16 & 53.33 & 17 & 56.67 & 6 & 20.00 \\
\hline Not adopted & 14 & 46.67 & 13 & 43.33 & 24 & 80.00 \\
\hline Total & 30 & 100 & 30 & 100 & 30 & 100 \\
\hline
\end{tabular}

after discussion with dealers and nearly half (41.20\%) of the respondents said that they will go for adoption only after discussion with fellow farmers.

\section{Technology advisories}

Result in the Table 1, shows that a majority $(73.33$ $\%)$ of the respondents were found to be old aged followed by middle aged $(20.00 \%)$ and remaining 6.67 per cent were young. About 40 per cent of the respondents were found to have undergone middle education followed by 30 per cent of the respondents had collegiate education followed by $26.67,3.33$ per cent of the respondents were under secondary and illiterate level of education. Nearly two-third (63.30 $\%$ ) of the respondents had medium level of farming experience and half $(50.00 \%)$ of the respondents were big farmers. It can be reported that from the results more than one-fourth $(26.67 \%)$ of the respondents had adopted the SMS based technology advisories.

From Table 2, it is found that meager proportion $(16.67 \%)$ of the respondents stated that they will go for direct adoption. Half of the respondents (50.00 $\%)$ mentioned that they will go for adoption of SMS advisories only after discussion with fellow farmers and 33.33 per cent of the respondents quoted 
that they will go for adoption only discussion with the dealers. Chi-square test was adopted for the independent variables viz., age, educational status, farming experience, farm size and interactivity with adoption to find out the association between variables.

Table 2. Farmer's Decision Making behavior on the adoption SMS based advisories

\begin{tabular}{lcccccc}
\hline $\begin{array}{l}\text { When will you get convinced to adopt } \\
\text { an advisory disseminated through }\end{array}$ & $\begin{array}{c}\text { Market advisory } \\
\text { SMS }\end{array}$ & No. & $\%$ & $\begin{array}{c}\text { Weather advisory } \\
\text { (ACRC) }\end{array}$ & $\begin{array}{c}\text { Technology advisory } \\
\text { (KVK) }\end{array}$ \\
\cline { 2 - 7 } & 7 & 43.75 & 7 & 41.20 & 3 & 50.00 \\
\hline Discussion with fellow farmers & 4 & 25.00 & 6 & 35.30 & 2 & 33.33 \\
Discussion with agro input dealers & 5 & 31.25 & 4 & 23.50 & 1 & 16.67 \\
Direct adoption based on SMS & 16 & 100 & 17 & 100 & 6 & 100 \\
Total (Adopted Farmers) & & & & & & No. \\
\hline
\end{tabular}

It is found that there is significant difference in distribution of respondents under different educational categories and interactivity among DEMIC, ACRC and KVK.

Table 3. Distribution of respondents based on perception towards SMS based advisory system

\begin{tabular}{lcc}
\hline Category & Frequency & Percentage \\
\hline Low & 2 & 2.20 \\
Medium & 79 & 87.80 \\
High & 9 & 10.00 \\
Total & 90 & 100 \\
\hline
\end{tabular}

It could be reported from the results of the independent sample t-test, there exists significant difference among the variables namely, age, educational status and farming experience.

\section{Farmer's perception towards SMS based advisories}

Based on the objectives of the study, the variable 'perception' has been operationalized as farmer's perception towards SMS based advisories. By percentage analysis, the respondents were categorized into low, medium and high based on their perception. From the Table 3, it could be revealed that a majority of the respondents $(87.80 \%)$ possessed medium level of perception towards SMS based advisories followed by high (10.00\%) and low (2.20 $\%)$ level of perception.

Table 4. Constraints faced by the farmers in accessing the required information through SMS

\begin{tabular}{lccc}
\hline Constraints in accessing information & No. of farmers & Per cent of farmers & Rank \\
\hline Irrelevancy of the messages & 25 & 27.78 & I \\
Lack of recommendation on latest technologies & 19 & 21.10 & II \\
Lack of trustworthiness of the messages & 14 & 15.56 & III \\
Lack of clarity on contents of the messages & 12 & 13.33 & $\mathrm{IV}$ \\
Incompatibility of hand set to receive Tamil version of SMS & 9 & 6.67 & $\mathrm{VI}$ \\
Illiteracy & 6 & 5.56 & $\mathrm{VII}$ \\
Anonymity of the source of SMS & 5 & 100 & 90 \\
Total
\end{tabular}

Majority of the respondents felt hat SMS based agro advisories were easy to handle, access, share, store and refer. These facts might have been the reason for medium to high level of perception as resulted in this study.

\section{Constraints faced by the farmers in accessing the SMS based advisories}

Though there are several ICT based extension approaches, the penetration of the ICT based agricultural service has not been practiced much among the farming communities (Singh et al., 2015). Based on the available information different constraints in disseminating mobile SMS based agro advisories were enlisted from respondents. Responses from farmers were recorded on individual ranking basis. Descriptive statistics was used for the interpretation of collected information.

During telephonic interview it is found that there existed a gap between farmers and extension personnel in terms of face to face interaction. We need to establish supporting infrastructure and capacity building to the farmers in order to utilize the mobile based agro advisories such as weather information, proper market information of a particular 
commodity and agricultural technology information. This derives support from the findings of Madan Singh et al. (2015). Most of the farmers reported that irrelevancy of the messages, lack of recommendation on latest technologies and lack of trustworthiness of the messages as the constraints in accessing the required information.

\section{Conclusion}

The study revealed that majority of the registered farmers $(64.00 \%)$ belonged to old age category with middle level of education, medium level of farming experience and possessed medium size of land holdings. Results showed that the adoption of SMS based advisories was low among registered farmers of KVK as compared to that of ACRC and DEMIC. Majority $(87.80 \%)$ of the respondents had medium level of perception towards SMS based advisories. Most of the farmers reported that irrelevancy of the messages and lack of recommendation on latest technologies as the prime constraints to access the required information. The following strategies are proposed for enhancing the effectiveness of mobile based SMS advisories.

a. Create awareness among farming community about mobile based SMS advisories.

b. Training may be given to the farmers about how to access SMS facilities in mobile.

c. Area specific and problem specific information should be provided to the farmers.

d. Experts and organizations must give appropriate reply to queries and information raised by the farmers.

\section{Policy implication}

The study implies that SMS advisories in agriculture can only create awareness and provide knowledge to farmers about technologies that exist to solve their field problems. Farmers cannot be convinced to go for field level adoption of technologies, directly by sending SMS advisories.
In the case of decision based SMS advisories such as Market and Weather information, a considerable proportion of farmers, go for adoption directly without having further discussion about SMS advisories. However, in the case of technologies recommended in the form of SMS advisories to solve field level problems such as management of disease / pest / weed / nutritional disorders in crops, a major proportion of farmers $(76.00 \%)$ had adopted such technologies only after having a discussion about the SMS with their fellow farmers and/or input dealers. This implies that ICT based extension services (e.g.: SMS advisories, websites, portal etc.) can be effective if it is combined with personal interaction of extension officials / experts who can convince the farmers, clarify doubts about SMS and motivate them to go for adoption of the recommended technologies.

\section{References}

Fafchamps, M. and Minten, B. 2011. Impact of SMS-Based Agricultural Information on Indian Farmers, World Bank Economic Review, 26(3): 383-414.

Jayanthi, M. and Asokhan,M. 2016. Perception of Farmers towards Mobile Agricultural Extension Services in Tamil Nadu, Advances in Life Sciences, 5(12): 4917 4920.

Madan Singh, R., Roy Burman, J., Sharma, P., Sangeetha ,V. and Iquebal, M.A. 2015. Constraints Faced in Mobile Based Agro-Advisory Services and Strategy for Enhancing the Effectiveness of mKRISHI, Indian Res. J. Ext. Edu. 15(2): 119- 122.

Mittal, S. and Mamta, M.A. 2012. How mobile phones contribute to growth of small farmers? Evidence from India, Quarterly journal of International Agriculture, 51(3): 227-244.

Saravanan, R. 2010. ICTs for Agricultural Extension: Global Experiments, Innovations and experience, New India Publishing Agency, New Delhi, p: 115-168.

Sidramappa V. Manige, Manjunath Patil, Pradeep Kumar, V. Kantharaju and Basava Prabhu. 2013. Impact of mobile phone on agriculture in Gulbarga district of Karnataka, Karnataka Journal of Agricultural Sciences, 26(4): 524-527.

http://agcensus.nic.in/document/agcensus $2010 /$ agcen2010rep.htm. 